\title{
Genomic Imprinting in Human Placenta
}

\author{
Luca Lambertini1 ${ }^{1,2}$, Men-Jean Lee ${ }^{3}$, Carmen J. Marsit ${ }^{4}$ and Jia Chen ${ }^{1,5,6}$ \\ ${ }^{1}$ Department of Preventive Medicine, \\ Mount Sinai School of Medicine, New York, \\ ${ }^{2}$ Department of Obstetrics, Gynecology and Reproductive Science, \\ Mount Sinai School of Medicine, New York, \\ ${ }^{3}$ Department of Obstetrics and Gynecology, \\ Indiana University-Purdue University, Indianapolis, \\ ${ }^{4}$ Department of Pharmacology and Toxicology, \\ Dartmouth Medical School, Hanover, \\ ${ }^{5}$ Department of Pediatrics, \\ Mount Sinai School of Medicine, New York, \\ ${ }^{6}$ Department of Oncological Sciences, \\ Mount Sinai School of Medicine, New York, \\ USA
}

\section{Introduction}

The placenta is a unique organ that supports and drives embryonic development by providing an environment for the growth of the fetus, coordinating the different phases of embryogenesis, and serving as an interface for maternal-fetal interactions. The placenta is a very dynamic organ, where a continuum of phenotypic and morphological changes takes place over the course of gestation. Such plasticity is achieved due to a unique epigenetic profile that allows for: 1) a rapid growth to timely accommodate the embryo; 2) a marked invasiveness that allows implantation and invasion of fetal cells into the maternal endometrium; and 3) a specific metabolic activity that spans from growth in a hypoxic environment, accession to the maternal blood supply, remodeling of endothelial cell functions, to evasion of the immune system, allocation of nutrient resources, disposal of fetal waste products, and production of pregnancy-associated hormones (Hu \& Cross, 2010).

Consistently, since the early 1980s, the placenta has been proven to possess an unusual epigenetic profile with the lowest level of genomic DNA methylation of all organs across different species (Ehrlich et al., 1982; Gama-Sosa et al., 1983). Under the assumption that DNA methylation leads to gene silencing, this hypomethylated profile has been attributed to the need for the placenta to sustain implantation with promotion of rapid and highly coordinated fetoplacental growth and maturation. Somewhat supportive of this hypothesis is the discovery that the placenta shares common epigenetic features with tumor tissues which display fast growth and invasive morphologic characteristics as well (Guilleret et al., 2009; Harada, 1978; Perry et al., 2010). 


\subsection{Placenta epigenetics and genomic imprinting}

The intricate network of epigenetic mechanisms that act on the genome modifying its expression to determine the phenotype is, as of yet, only poorly understood. DNA methylation, histone modification and long non-protein-coding RNAs (lncRNAs) activity are the best known of such mechanisms. While studies that explored each of these phenomena individually, either in a genome-wide or targeted fashion, struggled to determine the full extent of their importance (Lambertini et al., 2011), the integrated investigation of their interplay, in the framework of specific molecular pathways linked to phenotypical outcomes, is gaining momentum (Q. Li et al., 2011; Qureshi \& Mehler, 2011).

Genomic imprinting is probably the best example of how multiple epigenetic mechanisms act on the phenotype. It has in fact been shown that DNA methylation, histone modification and lncRNAs, coordinately act in regulating the monoallelic expression of a small subset of genes $(\sim 1 \%)$ in the human genome accordingly to their parent-of-origin. As for all other epigenetic mechanisms, imprinting shows tissue-specificity, i.e. genes that are imprinted in the placenta are biallelically expressed in other tissues (T.H. Vu et al., 2010). The loss of genomic imprinting (LOI) during the early stages of embryogenesis, can lead to placental and fetal growth restriction and influence the fetal development into adulthood (Sasaky \& Ishino, 2006; Tycko, 2006; American Journal of Medical Genetics, 2010).

Accordingly, experiments on mice showed that induced pluripotent stem cells (iPCs) and embryonic stem (ES) cells have indistinguishable global mRNA profiles; however iPCs fail to support the development of all-iPCs animals contrary to ES cells. A closer investigation of the iPCs and ES mRNA profiles however revealed a reproducible expression difference for only 2 transcripts, the lncRNA Meg3 and the small nucleolar RNA Rian, two imprinted genes belonging to the Dlk1-Dio3 imprinted domain. Additionally, the expression profiles of other imprinted gene sets were found to vary from clone to clone further supporting the critical role played by imprinted genes in development (Stadtfeld et al., 2010).

In another mouse model, bi-maternal embryos obtained from immature primordial oocytes, with no established epigenetic imprinting marks, and fully developed oocytes with complete sex-specific imprinting signals, were not viable. Placentas of these embryos showed both severe growth restriction and abnormal histology. The engineered deletion in primordial oocytes of two relatively small regions encompassing the two imprinted gene clusters Igf2-H19 and Dlk1-Dio3, alone rescued the phenotype. The placenta was then found to develop normally and the associated conceptuses grew normally into adulthood. Interestingly, embryos from one normal and one primordial oocyte, alternatively carrying only one of the imprinting deletions, resulted in phenotypes affecting placental growth and fetal development as well as size and general health status of the progeny (Kawahara et al., 2009).

These findings support the fundamental role that imprinted genes play in development while contemporaneously highlighting the need, for embryogenesis to proceed regularly, of the contribution of genotypes carrying different epigenetic marks (i.e. paternal and maternal), as shown in the early 1980s from studies in mice (McGrath \& Solter, 1984). This condition has been addressed by the "parental conflict theory" which proposes that the parent-of-origin specific epigenetic marks of genomic imprinting evolved in animals to properly allow for the distribution of maternal resources to each developing embryo (Haig 
\& Graham, 1991; Moore \& Haig, 1991). Under this theory a tug-of-war takes place between the paternally expressed genes that promote fetal growth to generate a stronger offspring, and the maternally expressed genes that have the opposite effect in order to preserve maternal energies (McGrath \& Solter, 1984). In line with this theory are the findings that paternal uniparental disomy (UPD) (paternalization) of the imprinted region of chromosome 11, which carries several imprinted gene clusters, results in the BeckwithWiedemann syndrome characterized by a birthweight $50 \%$ above normal, accompanied by other overgrowth symptoms. On the other hand, maternal UPD (maternalization) of this same region leads to Silver-Russell syndrome characterized by perinatal and postnatal growth deficiency (Barlow et al., 1991).

There are also evolutionary findings that support the parental conflict theory. Humans in fact show a diminished degree of conservation of the genomic imprinting, particularly for maternally expressed genes (Hutter et al., 2010), compared to lower species. This is consistent with the observation that singleton pregnancies are much more common in humans therefore reducing the need of conservation of maternal energy (Isles, 2009; Monk et al., 2006).

Analysis of the LOI in normal placenta provides additional clues on possible relaxation of the imprinting status in humans. Normal placenta samples in fact returned appreciable LOI values (>3\%) for genes like IGF2, MEST, PEG3, SLC22A18 and TP73 in a pilot study run by measuring LOI in a highly quantitative allele-specific real-time PCR (RT-PCR) on 22 placental RNA samples across 14 imprinted genes (Diplas et al., 2009a; Lambertini et al., 2008; Lambertini et al., 2009). It has however to be noticed that 3 out of the 5 genes identified were paternally expressed (or maternally imprinted) and 2 maternally expressed (or paternally imprinted) which speaks more directly for a generalized LOI of imprinted genes independently from their parent-of-origin.

\subsection{Genomic imprinting characteristics}

The mechanism by which DNA methylation, histone modification and lncRNAs operate in silencing genes accordingly to their parent-of-origin is becoming more and more clear as evidence accumulates, even though several points still remain obscure.

Imprinted genes often reside in clusters spread across all human genome and are expected to represent only around $1 \%$ of the expressed genes or 200 genes; of these at present only $\sim 90$ have been experimentally proven. Imprinted genes, both when alone or clustered, are invariably regulated by imprinting control regions (ICRs) that determine the silent/active status of one of the alleles. ICRs are short DNA sequences with limited shared features that show allele-specific methylation at consensus $\mathrm{CpG}$ dinucleotides involved in the binding with regulatory proteins. Functional CpG dinucleotides invariably appear as $50 \%$ methylated. Such attributes were discovered in a total of 8 imprinted clusters both in mice and humans overlooking the allele-specific expression of a total of nearly 30 genes (Lewis \& Reik, 2006). ICR-like features have been shown for 5 other regions which have at present been linked to a single imprinted gene. The remaining imprinted genes returned mostly parent-of-origin specific methylation of the promoter region. ICRs can ultimately be located several kilobase pairs (kbp) away from a specific imprinted gene, in non-coding genomic areas or in the promoter or gene body of other imprinted genes (Lewis \& Reik, 2006). 
DNA methylation was for several years thought to be the only epigenetic mechanism regulating imprinting, recently however experiments on histone modification showed that ICRs carry characteristic features of allele-specific methylation of histone $\mathrm{H} 3$, acetylation of histones $\mathrm{H} 3$ and $\mathrm{H} 4$ and ubiquitination of histone $\mathrm{H} 2$ over specific lysine aminoacidic residues. These epigenetic signals have been linked with the stabilization of the active/silenced status of each allele (Gieni \& Hendzel, 2009; Yang \& Kuroda, 2007).

One question has however always been left unanswered, how can an ICR regulate the silencing of one allele of a gene located up to $100 \mathrm{kbp}$ away? The answer to this question was tentatively provided by the discovery of IncRNAs. These molecules, which are not translated into proteins, are actively transcribed, have lengths often above 1,000 bp and carry consensus sequences for the binding of regulatory proteins complexes that can also bind ICRs (Bernstein \& Allis, 2005). Accordingly, lncRNAs are ideal candidates for determining spatial and temporal specificity as transcription regulators by interacting with their promoters in a temporally regulated fashion (Mohammad et al., 2009; Yazgan \& Krebs, 2007). From the mechanistic point of view it has been proposed that lncRNAs act by directly recruiting chromatin modifying proteins that would participate in the formation of DNA loops intended to activate/silence genes and even select between promoters with different strength (Lefevre et al., 2008).

Interestingly only $1.5 \%$ of our entire genome encodes mRNAs that are translated into proteins while $60-80 \%$ of the genome is transcribed into non-protein-coding RNAs (Lee, 2009). Also while the number of nucleotides encoding protein sequences is relatively constant, the number of nucleotides for non-protein-coding sequences increases over a wide range of eukaryotic complexity, suggesting that increased complexity itself may be explained by an increase in cis-acting regulatory elements driving trans-acting lncRNAs (Taft et al., 2007). It has now been proposed that lncRNAs act on silencing specific alleles much the same way that the XIST IncRNA acts on silencing one of the X chromosome copies in females. In this model, DNA methylation and histone modification marks would act as readout signals for lncRNA-protein complexes (Heard et al., 2004). Accordingly, each of the identified imprinted clusters expresses at least one lncRNA (Bartolomei, 2009).

An indirect confirmation of this model comes from the discovery that LOI is a cell-specific phenomenon. It has been in fact shown in cell lines that the administration of 5-aza-2'deoxycytidine (AZA) induces complete bi-allelic expression in individual clones (Diplas et al., 2009b). This finding is thus consistent with a total erasure of the DNA methylation readout code therefore leading to a complete binding inhibition of the protein complexes that would otherwise drive the allele silencing.

\section{Imprinted genes and development}

Epigenetic imprinting signals are timely reset during the zygote pre-implantation and early implantation phases. It has been hypothesized that at this stage the embryo undergoes to a basic programming in order to develop according to the environmental conditions it would face after birth (Santos \& Dean, 2004).

During pre-implantation the zygote is subjected to a genome-wide wave of de-methylation intended to reset this epigenetic signal brought about by the parents. Re-methylation of genomic regions takes place accordingly to the new fetal programming. ICRs and ICR-like 
elements on paternal and maternal alleles are however protected from such changes and maintain their parent-of-origin original configuration (Figure 1) (Perera \& Herbstman, 2011). The hypothesis behind this phenomenon is that, at fertilization, paternal and maternal haploid genomes still carry their own epigenetic effector protein complexes that act by differentially binding to chromosomal regions to generate sex-specific tridimensional organization of the genome. This theory finds a further explanation while looking at the first genome-wide de-methylation wave of non-imprinted regions; paternal and maternal genomes are in fact stripped at this stage of their DNA methylation signals at a different rate with the paternal genotype becoming quickly unmethylated after fertilization while the maternal de-methylation proceeds slowly (Reik et al., 2001). Following the resetting of the DNA methylation profiles in a cell type specific fashion, the histone code is reset to further

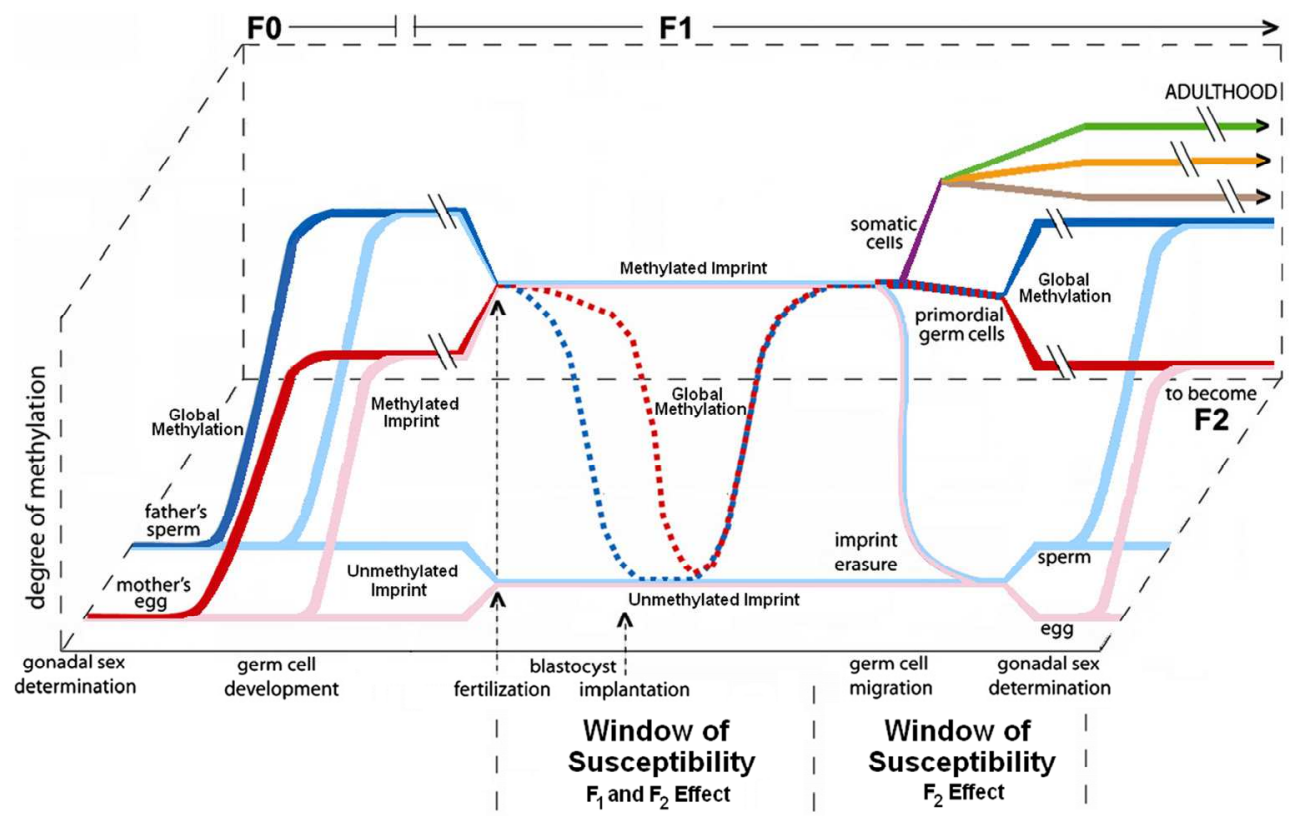

Fig. 1. Fetal imprinting reprogramming of DNA methylation marks during the early zygote developmental phases. $\mathrm{F}_{0}$ sperm and egg carry global (red and blue lines) and imprintingspecific methylation signals (pink and light blue). After fertilization global methylation is reprogrammed at the blastocyst stadium. Imprinting signals are however maintained unaltered to generate an embryo with distinct parental contributions. Imprinting reprogramming takes place only in the primordial germ cells later in development to generate gametes carrying imprinting marks according to the sex of the developing embryo. Perturbations of the imprinting profiles at the blastocyst stage can directly affect the embryo and also the gametes ( $F_{1}$ and $F_{2}$ windows) Perturbations happening later affect specifically imprinting reprogramming of gametes $\left(\mathrm{F}_{2}\right.$ window). Somatic cells separately develop from the embryo carrying the parental imprinting signals and the newly reprogrammed global methylation setting (purple line). They later rearrange their methylation status coherently with the adult tissue they will originate (green, orange and brown lines). [Adapted from (Perera \& Herbstman, 2011)]. 
stabilize the DNA methylation profile providing the embryo with the articulated network of epigenetic signaling carrying the essential parent-of-origin specific setup of the genome (Santos \& Dean, 2004).

Later in fetal development a subset of embryonal cells are selected to become primordial germ cells (PGCs). In order to guarantee the generation of mature haploid germ cells with imprinting marks consistent with the sex of the developing embryo, PGCs undergo to a second DNA de/re-methylation programming and histone coding this time specifically targeted to imprinted domains (Reik et al., 2001).

Embryonic DNA methylation and histone modification signals placed in the early zygote during these developmental stages together constitute the "code" for lncRNAs to later "read" to drive, similarly to the $X$ inactivation process, the gene silencing/activation in a plastic and adaptable system during subsequent developmental phases. This same system would also determine the tissue specificity of imprinting as shown in the liver where the IGF2-H19 ICR is still paternally methylated but IGF2 is biallelically expressed (T.H. Vu et al., 2010).

This highly coordinated system of epigenetic reprogramming creates windows of vulnerability during the early phases of the fetal development that extends into the later phases, as well as exerting a trans-generational effect when perturbing the correct PGCs programming. Such perturbations, depending from the time of occurrence, can in fact extend their effect across at least the second generation (Figure 1) and possibly even beyond. In this framework, it has been hypothesized that several fetal outcomes can be associated with perturbations of the embryo epigenetic reprogramming at different times across the windows of susceptibility (Table 1).

Between these episodes, the prenatal and periconceptional exposure to insufficient maternal caloric intake has been found to leave lasting signals on the methylation profile of several imprinted genes like INS, IGF2, GNASAS and MEG3 up to 60 years after the triggering event. This environmental phenomenon has also been reported to act in a sex-specific way with a strict dependence from the exposure timing. Exposures happening late in the pregnancy in fact do not leave persistent changes on the methylation profiles (Tobi et al., 2009). Epidemiologic investigations on exposed subjects concomitantly revealed high rates of behavioral disorders and obesity (Lumey, 1998; Roseboom et al., 2006; Susser et al., 1998), as confirmed by other investigations in populations with similar exposures (Song et al., 2009).

The key role of imprinted genes in placental and fetal development is further shown when investigating the other genes with which they network by using informatics tools such as Ingenuity Pathway Analysis (IPA) (Ingenuity ${ }^{\circledR}$ Systems - www.ingenuity.com). Imprinted gene pathway analyses in fact link these genes to three main areas: 1) cell proliferation, assembly, organization, cycling and death; 2) metabolism of lipids and other small intracellular signaling molecules that bind proteins and nucleic acids to regulate their activity and/or function; and 3) development and function of nervous system, respiratory system and other organs. At the same time these genes are listed in the pathways leading to developmental, neurological, psychological, skeletal, muscular, genetic, cardiovascular, gastrointestinal, hepatic and connective tissue disorders together with cancer in agreement with the common epigenetic setting of placental and tumor tissues (Table 2). 


\begin{tabular}{|c|c|}
\hline Event & Reference \\
\hline $\begin{array}{l}\text { 1. Phocomelia from prenatal exposure to thalidomide as } \\
\text { antiemetic in early pregnancy }\end{array}$ & $\begin{array}{l}\text { (McBride, 1961) } \\
\text { (Taussig, 1962) }\end{array}$ \\
\hline $\begin{array}{l}\text { 2. Cerebral palsy, mental retardation, and convulsions from } \\
\text { prenatal exposure to methyl mercury from contaminated fish }\end{array}$ & $\begin{array}{l}\text { (Ordonez et al., 1966) } \\
\text { (Pierce et al., 1972) } \\
\text { (Bakir et al., 1973) } \\
\text { (Harada, 1978) }\end{array}$ \\
\hline $\begin{array}{l}\text { 3. Reduced birth weight and increased incidence of preterm birth } \\
\text { from prenatal exposure to maternal smoking }\end{array}$ & $\begin{array}{l}\text { (Underwood et al., 1967) } \\
\text { (Meyer et al., 1976) }\end{array}$ \\
\hline 4. The fetal alcohol syndrome & $\begin{array}{l}\text { (Lemoine et al., 1968) } \\
\text { (Ulleland, 1972) } \\
\text { (Jones \& Smith, 1973) }\end{array}$ \\
\hline $\begin{array}{l}\text { 5. Diminished intelligence and shortening of attention span from } \\
\text { prenatal exposure to lead }\end{array}$ & (Landrigan et al., 1975) \\
\hline $\begin{array}{l}\text { 6. Clear cell adenocarcinoma of the vagina in young women from } \\
\text { prenatal exposure to the synthetic estrogen diethylstilbestrol } \\
\text { administered in pregnancy to prevent premature labor }\end{array}$ & (Herbst et al., 1981) \\
\hline $\begin{array}{l}\text { 7. Neural tube defect from prenatal exposure to folic acid } \\
\text { deficiency }\end{array}$ & (Molloy et al., 1985) \\
\hline $\begin{array}{l}\text { 8. Low birth weight from prenatal treatment with multiple } \\
\text { courses of antenatal glucocorticoids }\end{array}$ & $\begin{array}{l}\text { (Doyle et al., 1989) } \\
\text { (Thorp et al., 2002) }\end{array}$ \\
\hline $\begin{array}{l}\text { 9. Behavioral disorders and obesity from prenatal and } \\
\text { periconceptional exposure to insufficient maternal caloric } \\
\text { intake }\end{array}$ & $\begin{array}{l}\text { (Susser et al., 1996) } \\
\text { (Lumey, 1998) } \\
\text { (Roseboom et al., 2006) }\end{array}$ \\
\hline $\begin{array}{l}\text { 10. Reduced head circumference at birth from prenatal exposure to } \\
\text { organophosphate insecticides }\end{array}$ & $\begin{array}{l}\text { (Perera et al., 2003) } \\
\text { (Eskenazi et al., 2004) }\end{array}$ \\
\hline $\begin{array}{l}\text { 11. Shorter anogenital distance and poorer semen quality in males } \\
\text { from prenatal exposure to phthalates }\end{array}$ & $\begin{array}{l}\text { (Swan et al., 2005) } \\
\text { (Mendiola et al., 2011) }\end{array}$ \\
\hline $\begin{array}{l}\text { 12. Reduced intelligence from prenatal exposure to } \\
\text { polychlorinated biphenyls (PCBs) }\end{array}$ & $\begin{array}{l}\text { (Engel et al., 2007) } \\
\text { (Wolff et al., 2007) }\end{array}$ \\
\hline $\begin{array}{l}\text { 13. Reduced intelligence and slowed mentation from prenatal } \\
\text { exposures to arsenic and manganese in drinking water }\end{array}$ & $\begin{array}{l}\text { (Khan et al., 2011) } \\
\text { (Parvez et al., 2011) }\end{array}$ \\
\hline
\end{tabular}

Table 1. Neonatal outcomes associated with perturbations of the embryo epigenetic reprogramming at different times across the windows of susceptibility. 


\begin{tabular}{|c|c|c|}
\hline \multirow{2}{*}{$\begin{array}{l}\text { Imprinted Genes } \\
\text { by Network(2) }\end{array}$} & \multicolumn{2}{|c|}{ Networks } \\
\hline & Functional Areas & Associated Disease \\
\hline $\begin{array}{l}\text { 1. CCNE1, CDKN1C, CYR61, } \\
\text { DLK1, E2F7, GDNF, GRB10, } \\
\text { H19, HOXD10, IGF2, } \\
\text { KCNQ1, MAPK12, NGFB, } \\
\text { NNAT, PCNA, SNURF, } \\
\text { TP73, WT1 }\end{array}$ & $\begin{array}{l}\text { Cellular Growth } \\
\text { Proliferation }\end{array}$ & $\begin{array}{l}\text { Developmental Disorders } \\
\text { Genetic Disorders }\end{array}$ \\
\hline $\begin{array}{l}\text { 2. BMPR2, DLGAP2, GRIA1, } \\
\text { HOXA11, HTR2A, INS, } \\
\text { MAGI2, NEDD9, PEG3, } \\
\text { PPP1R9A, SHANK2, } \\
\text { SNRPN, UBE3A }\end{array}$ & Nervous System Dev \& Funct & $\begin{array}{l}\text { Cancer } \\
\text { Skeletal \& Muscular Disorders } \\
\text { Reproductive System Diseases }\end{array}$ \\
\hline $\begin{array}{l}\text { 3. CD44, DIRAS3, DLX5, } \\
\text { EPS15, IL1B, ILK, NDN, } \\
\text { NLRP2, TFPI2 }\end{array}$ & $\begin{array}{l}\text { Cellular Development } \\
\text { Cell Cycle }\end{array}$ & Cardiovascular Diseases \\
\hline $\begin{array}{l}\text { 4. ATP10A, CCDC86, } \\
\text { CDKAL1, SGCE, SLC22A3, } \\
\text { SLC22A18AS }\end{array}$ & Small Molecule Biochemistry & $\begin{array}{l}\text { Gastrointestinal Diseases } \\
\text { Hepatic System Diseases }\end{array}$ \\
\hline $\begin{array}{l}\text { 5. CTAG2, CTNND2, } \\
\text { L3MBTL, MEST, OSBPL5, } \\
\text { PLAGL1, TCEB3C }\end{array}$ & Gene Expression & $\begin{array}{l}\text { Cancer } \\
\text { Connective Tissue Disorders }\end{array}$ \\
\hline $\begin{array}{l}\text { 6. COPG2, CPA4, DHCR24, } \\
\text { PEG10, ZNF331 }\end{array}$ & $\begin{array}{l}\text { Cell Cycle } \\
\text { Cellular Development }\end{array}$ & Cancer \\
\hline $\begin{array}{l}\text { 7. CTNNA3, KCNQ1OT1, } \\
\text { PHLDA2 }\end{array}$ & $\begin{array}{l}\text { Organ Development } \\
\text { Respiratory System Dev \& Funct } \\
\text { Cell Assembly \& Organization }\end{array}$ & - \\
\hline 8. GFI1, GNAS, LASS4, LMO1 & $\begin{array}{l}\text { Lipid Metabolism } \\
\text { Small Molecule Biochemistry } \\
\text { Cell Death }\end{array}$ & - \\
\hline $\begin{array}{l}\text { 9. GABRA5, GABRB3, } \\
\text { GABRG3 }\end{array}$ & - & $\begin{array}{l}\text { Neurological Diseases } \\
\text { Developmental Disorders } \\
\text { Psychological Disorders }\end{array}$ \\
\hline 10. KCNK9 & Cell Death & Neurological Diseases \\
\hline 11. MEG3 & Connective Tissue Dev \& Funct & Behavioral Syndromes \\
\hline 12. SDHD & - & $\begin{array}{l}\text { Cancer } \\
\text { Endocrine System Disorders } \\
\text { Genetic Disorders } \\
\end{array}$ \\
\hline 13. SLC22A18 & - & \begin{tabular}{|l} 
Cancer \\
Developmental Disorders
\end{tabular} \\
\hline
\end{tabular}

(1): it includes only those genes for which a gene network of reference could be found by imputing all imprinted genes experimentally proven.

(2): networks include biallelically expressed genes not listed here for ease of reading.

Table 2. Function and Disease Association of IPA networks including imprinted genes(1) 
It is not surprising that studies in animal models pointed out the importance of imprinted genes in the placental and fetal development and phenotype determination (Bressan et al., 2009). Around $70 \%$ of the known imprinted genes are in fact expressed in placenta (Diplas et al., 2009a). A first classification of the role that imprinted genes play in development has been recently carried out in mice that divided them into genes express exclusively in the placenta and genes expressed in both placenta and embryo. The first group is made out of genes that regulate the exchange of resources between mother and fetus and are often found imprinted only in the placenta. The second group has instead been further subdivided into: 1) genes that program the metabolism in the early postnatal period to determine growth and metabolic phenotype that greatly affect the survival of the offspring; and 2) genes that participate in the development of metabolic organs such as the pituitary and pancreas, energy processing and storage organs like liver and fat, the hypothalamus and the placenta. Imprinted genes of this subgroup have been linked to growth retardation, and brain, bone, muscle and liver disorders (Charalambous et al., 2007).

Characteristic expression profiles of imprinted genes have also been described for the placenta and endocrine tissues across species with an associated specific pattern of transcription factor binding sites suggestive of the critical role they play in these tissues (Steinhoff et al., 2009).

Additionally it has been shown that the expression of imprinted genes in placenta is tightly regulated compared to other genes (Diplas et al., 2009a). Low transcriptional noise has been reported for genes that substantially affect the phenotype (Elowitz et al., 2002; Ozbudak et al., 2002), lead to lethality (Blake et al., 2003; Fraser et al., 2004), show haploinsufficiency (Batada \& Hurst, 2007). Given their role and their functionally haploid status, imprinted genes have been proposed to belong to this group (Zaitoun et al., 2010).

\section{Imprinted genes dysregulation in fetoplacental development}

Intra-uterine growth restriction (IUGR) and preeclampsia (PE) are by far the most common pregnancy outcomes and alone they account for about a third of all preterm births (Little, 2009). Both IUGR and PE are considered placentation disorders that arise from shallow trophoblast invasion with characteristic tissue morphology that leads to uteroplacental insufficiency. At the same time a vast body of literature has linked poor placentation with numerous chronic and developmental disorders in children (Barker, 1997; Godfrey \& Barker, 2000; Heijmans et al., 2007) spanning from asthma (Federal Interagency Forum on Child and Family Statistics, 2011; US Environmental Protection Agency [US EPA], 2010;) and obesity (Centers for Disease Control [CDC], 2011) to neurodevelopmental syndromes (Boyle et al., 1994; CDC, 2009), learning disabilities (Pastor \& Reuben, 2008), birth defects (Paulozzi et al., 1997; L.T. Vu et al., 2008) to even cancer (National Institutes of Health/National Cancer Institute [NIH/NCI], 2011).

Together these diseases all fall in the category of those that would greatly benefit from the availability of early diagnostic tools to give healthcare providers an opportunity for intervention/prevention to impact the quality of life of the affected subjects and to substantially contain the public health expenditure. The development of such epigenetic tools into biomarkers for prenatal diagnosis during pregnancy would also extend their clinical utility. 
Analyses of the epigenetic profiles associated with IUGR and PE have revealed a substantial correlation with perturbations of the genomic imprinting settings particularly for growth restriction. These findings are not surprising in light of the role of imprinted genes in regulating placental and fetal development. However links are still lacking that unequivocally connect LOI to chronic and developmental syndromes.

\subsection{Pregnancy outcomes}

The first approach developed to investigate the correlation between LOI and IUGR was simply based on the analysis of the ICRs methylation status in placentas from uncomplicated fetuses and placentas from IUGR fetuses at term. Studies have focused on the first identified and extensively characterized IGF2-H19 ICR, also known as IC1 or ICR1, because of the experimentally proven opposite effects of IGF2 paternalization and maternalization on the embryonic growth. The IGF2-H19 ICR displays typical silencing features on the paternal allele including DNA methylation and histone inactivation signals absent on the maternal allele, which result in IGF2 expression from the paternal allele and H19 from the maternal (Lewis \& Reik, 2006). Such studies however failed to provide a clear answer, while in fact some investigations found a correlation with loss of methylation at the IGF2-H19 ICR and IUGR (Bourque et al., 2010) others showed no differences (Tabano et al., 2010).

At the same time it has been shown that IUGR induces contained dysregulation of a small subset of imprinted genes (Diplas et al., 2009a). Between them there is PHLDA2, a gene that showed a very consisted but contained upregulation in IUGR. This conclusion, while in line with previous studies (McMinn et al., 2006), has also been recently proven in studies on mice where animals were engineerized to double the Phlda2 dosage. Mice placentas showed a dramatic reduction of the junctional zone and perturbations of the glycogen metabolism that led to the restriction of the embryonic growth (Tunster et al., 2010). Such findings are consistent with the putative role attributed to PHLDA2 as a pleckstrin-homology protein involved in intracellular signaling via the binding of lipids within biological membranes. There is however no evidence that correlates the expression upregulation of PHLDA2 with methylation changes of the PHLDA2 ICR (KvDMR). The same has been shown for other dysregulated imprinted genes in IUGR (Diplas et al., 2009a ; Guo et al., 2008).

Recently a new approach has been developed that determines LOI by highly quantitative allele-specific RT-PCR using non-functional single nucleotide polymorphisms (SNPs) at the RNA level (Lambertini et al., 2008). By measuring the RNA relative amounts produced by each allele, the effect of all known epigenetic signals is taken into account. The analysis of these values in normal and IUGR placentas produced two main conclusions: 1) LOI is a common phenomenon in human placenta affecting different genes at different extents even in morphologically normal tissues; and 2) LOI differentially affects imprinted genes with some of them showing widespread appreciable values unrelated to the tissue morphology (e.g. IGF2, MEST, PEG3, SLC22A18, TP73), some others that are invariably imprinted with again no morphological correlation (e.g. CD44, EPS15, MEG3, PEG10, PHLDA2), and some other genes that show consistent LOI values only in IUGR placentas (e.g. DLK1, H19, PLAGL1, SNRPN). 
Quantitative LOI data however showed no correlation with gene expression which, challenges the dogma that LOI leads to the reactivation of a silent allele and results in increased expression of the affected gene(s). These findings are however in line with new studies that instead tie genomic imprinting to the tridimensional chromosome organization into physically organized expression networks. In this model lncRNAs, while still tethered to the genome during their transcription, would act by recruiting DNA binding proteins into complexes that interact with ICRs generating anchoring points for structural proteins that would pull genomic regions together into transcriptional hotspots (Court et al., 2011; Horike et al., 2005). The disruption of this genomic architecture would lead to uncoordinated activation/silencing of imprinted genes (Minard et al., 2009; Zlatanova \& Caiafa, 2009). In this framework, still to be clarified is the differential role played by the parental origins.

PE and IUGR share common pathological features even though they develop into distinct outcomes with also different clinical progression. It is therefore expected that the two outcomes also share common LOI profiles. While logical however this conclusion cannot be drawn as of yet. Few data in fact exist on the correlation of genomic imprinting with PE. A study on mice in fact proved that dysregulation in pregnant females of the expression of the paternally imprinted/maternally expressed $C d k n 1 c$ imprinted gene, a potent inhibitor of several cyclin/cyclin dependent kinase complexes, leads to PE-like symptoms including hypertension, proteinuria, thrombocytopenia, decreased anti-thrombin III activity, and increased endothelin levels in late pregnancy. However no data exist that reported LOI of CDKN1C in human preeclampsia (Kanayama et al., 2002). More recently instead correlations have been found between LOI of H19 and PE in humans (L. Yu et al., 2009).

Association of perturbations of genomic imprinting with other outcomes has mostly been hypothesized about preterm birth given the substantial contribution of the female line (Boyd et al., 2009; Little, 2009).

\subsection{Fetal neurodevelopment}

There is a growing recognition of the importance of the intrauterine period of development on health and disease throughout life, including mental health. Particularly, research is focused on the placenta which serves as the master regulator of the intrauterine environment and plays a functional role in shaping fetal development including neurodevelopment. These effects are modulated by simultaneous production of many pregnancy related hormones, proteins and growth factors thereby fulfilling a critical role in proper intrauterine development. Specifically, the placenta has been shown to produce an array of neuropeptide hormones that are analogous to those produced by the hypothalamus and pituitary of the brain, including GnRH, TRH, GHRH, CRH, and oxytocin (Liu, 2009). Rapid advancements in discovery of integrated regulation of neuropeptide homeostasis within and outside the brain as well as placenta (Petraglia et al., 1991; Yen, 1991, 1994) has led to the formulation of a new concept that the placenta acts as the "third brain" that links the developed (maternal) and developing (fetal) brains (Yen, 1994). In turn, alterations to this critical neurodevelopmental function may be a major contributor to the pathophysiology of intrauterine insults including illicit drug exposures (Lester \& Padbury, 2009).

Although alterations to the development of the hypothalamic-pituitary-adrenal (HPA) axis are likely critical mediators of appropriate infant neurodevelopment, it is also clear that 
additional genes and pathways may be affected by the maternal environment (Fink et al., 2010), and specifically that alterations to imprinted genes can play a crucial role in neurodevelopment. A high proportion of identified imprinted genes are expressed in the central nervous system. Maternally expressed imprinted genes are thought to favor the development of larger brains (Davies et al., 2005). Children with Beckwith-Wiedemann syndrome, which results in part from inappropriate imprinting of specific imprinted gene clusters, demonstrate greater than expected proportions of abnormal scores on emotional and behavioral scales (Kent et al., 2008). These observation were also confirmed in animal models, wherein female mice engineered to be null for the paternally expressed imprinted Peg3 gene, exhibit a reduced number of oxytocin-producing neurons in the hypothalamus, linking imprinted gene expression to neurodevelopment (L. Li et al., 1999). Recent work has also demonstrated that alterations in imprinted gene expression in the placenta are associated with infant neurodevelopmental outcome as reflected in prospectively validated neurobehavioral measures, and that specifically imprinted genes such as MEG3, HOXA11, and HOXD10, which are involved in nervous system, skeletal, and muscular development may be mediating these effects (Marsit et al., 2011). Additional research is needed to better dissect the roles of individual imprinted genes on infant neurodevelopment and to link these alterations to later life mental health and disease.

\subsection{Obesity}

As expected by the role that imprinted genes play in the development of metabolic organs that we previously outlined, obesity has been linked to imprinted genes dysregulations both in experimental animals and in epidemiologic investigations.

Knockout mouse models of heterozygous disruption of the imprinted gene Gnas, encoding the heterotrimeric $G$ protein alpha-subunit that coordinates the stimulation of the adenylyl cyclase, returned obese mice following the inactivation of the maternal allele and slim mice when the paternal allele was disrupted. Interestingly homozygous knockout mice were not viable (L. Yu et al., 2009; S. Yu et al., 2000). These data were later confirmed in humans (Plagge et al., 2008) and support the link between obesity and imprinted genes dysregulation that was already describe in the mid 1970s while analyzing a population of young men conceived during a famine episode in the Netherlands (Ravelli et al., 1976). This same population was later shown to carry an altered DNA methylation profile in the IGF2-H19 region (Heijmans et al., 2007; Tobi et al., 2009). In agreement with these are the numerous studies that linked metabolic alteration and overgrowth with disturbances of the imprinting profile (Barlow et al., 1991; Bressan et al., 2009).

\section{The proposed role of genomic imprinting in fetoplacental development}

Placental and fetal developments are accomplished across the relative short period of time of the pregnancy, therefore requiring a highly coordinated regulation of the genome to support the different phases of this process. The correct development can thus be achieved only by the activation of plastic and adaptable systems that are able to timely rearrange the functioning genes based on changes in the environment and the developmental program. Genomic imprinting is emerging as the best candidate for such role. It has been in fact shown that imprinted genes have a different level of imprinting in placenta during pregnancy. First trimester placentas return widespread higher LOI values compared to term placentas (Pozharny et al., 2010; L. Yu et al., 2009). 
Specifically genes like CD44 and EPS15 show a drastic LOI reduction from the first to third trimester of pregnancy (Pozharny et al., 2010). These data are particular interesting if we consider that CD44 is translated into a protein that participates in cell-cell interactions, adhesion and migration, and it has been tied to tumor metastasis promotion. Given the very fast growing and invasive nature of the placenta in the first trimester, CD44 would therefore be critical for supporting this phase. EPS15 instead encodes a peptide involved in receptormediated endocytosis of the epidermal growth factor; this gene has been linked to acute myelogenous leukemia. EPS15 would thus represent a key player in the process of establishing the appropriate maternal blood supply in the placenta to assist the fetal growth. The analysis of these findings supports the hypothesis that the "gain of imprinting" of imprinted genes during the different stages of fetoplacental development would add an additional layer of control on their activity. It has been proposed that this phenomenon is driven by the timely activation of effectors lncRNAs (Kacem \& Feil, 2009), of which imprinted genes are substantially provided, that act by silencing one gene copy accordingly to the parent-of-origin, similarly to other known lncRNAs as XIST and HOTAIR (Gupta et al., 2010; Lee, 2009). It is however not known why this process silence one specific allele and take place without altering the resulting expression profile of these genes.

Similar findings were recently reported in cultured human PGCs. In this model imprinting of some genes appeared very early after fertilization, while other genes showed complete imprinting only starting at 5 to 11 weeks after fertilization (Crane et al., 2009), again demonstrating the plasticity of this epigenetically driven phenomenon.

The common opinion that is gaining support is that genomic imprinting bimodally acts by adding layers of controls on the genome to regulate its activity according to environmental signals. This theory is supported by experiments on animals that showed that both in early developmental phases and in adult life, environmental signals trigger the activation of pathways that modify the complex epigenetic signaling controlling gene expression (Reik et al., 2001; Santos \& Dean, 2004). These studies provide critical information on the effect of the gene-environment interplay on the physiology of organisms (Zhang \& Meaney, 2010). An example of this condition in humans is represented by the data indicating that common environmental changes (such as dietary changes) may result in statistically significant epigenetic variations on DNA methylation of imprinted loci (Tobi et al., 2009).

In the bimodal imprinting model, DNA methylation and histone modification signals are placed on the genome very early in development when the zygote reprogramming takes place. They represent the first event leading to imprinting. Perturbations of this phase would most probably lead to the more severe effects on growth and development because it deprives the genome of the critical anchors for the imprinting machinery to recognize the areas to act upon. This hypothesis is confirmed, both at the genetic and epigenetic level, by studies on severe neurodevelopmental syndromes such as Prader-Willi and Angelman which have been correlated to inappropriate imprinting at the chromosome location 15q11 (Driscoll et al., 1992; Hamabe et al., 1991; Williams et al., 1990). Additionally, immediately after implantation, PGCs are selected to be programmed accordingly to the sex of the developing embryo; at this stage the improper placement of epigenetic signals acquires its transgenerational meaning. PGCs programming in fact is supposed to work by applying the epigenetic "code" of the allele consistent with the fetal sex, to the other allele. If "code" perturbations have been generated during the zygote reprogramming, they are therefore 
passed into PGCs. Accordingly, it has recently been shown that, during pregnancy, maternal exposure to phthalates, a family of chemicals with known potential for the perturbation of the epigenetic profile, specifically target the correct male fetal development. Male babies from exposed mothers show reduced anogenital distance and, later in life, low sperm count (Mendiola et al., 2011).

lncRNAs represent instead the second level of imprinting. lncRNAs act by assembling protein complexes that have several functions spanning from the regulation of the activity of enhancers (Mohammad et al., 2009), assembly of transcription complexes (Royo \& Cavaille, 2008) to generation of transcriptional hotspots (Yang \& Kuroda, 2007). The timely expression of these molecules is critical for the proper activation/silencing of gene sets. Later in life, lncRNAs would also restore biallelic expression of genes accordingly to the tissue, possibly also leading to a loss of methylation of unused and unprotected ICRs (Gieni $\&$ Hendzel, 2009). Perturbations of this second regulation layer would give way to other, possibly less severe and reversible, syndromes.

LOI has been implicated in the etiology of growth restriction syndromes and both conditions have been independently associated with chronic and developmental disorders that greatly impact the health of children - Barker Hypothesis (Barker, 1997) - with the potential of limiting their quality of life into adulthood, often resulting in reduced life expectancy. Chronic disorders in young adults also entail a great deal of expenditure due to the necessary life-long treatments (Landrigan \& Goldman, 2011; Trasande, 2011; Trasande \& Liu, 2011). The study of perturbations in genomic imprinting can shed light into the mechanisms leading to these disorders. The complete characterization of LOI also bears the promise of developing its highly quantitative measurement into new groundbreaking biomarkers that could have a major impact on public health by allowing early diagnosis of several pathologies correlated with placentation disorders, as well as on biomedical, behavioral and clinical research (Maccani \& Marsit, 2009). The completion of the analysis of the imprinting in placenta at different developmental stages is critical to achieve this goal (Pozharny et al., 2010).

After this, the next logical step is to develop a method that allows monitoring the imprinting status during pregnancy. New technological tools are now available to carry out quantitative RT-PCR experiments on single DNA/RNA molecules therefore opening the way to the challenge of measuring LOI in cells isolated from the amniocentesis fluid or from chorionic villi sampling (CVS). These advancements could be an opportunity to predict those pregnancies at risk of developing obstertrical disorders such as PE or IUGR and even fetuses at risk for future diagnosis of developmental diseases back to the first trimester of pregnancy.

\section{Acknowledgments}

This work was supported by the Venture Capital Research Funding Program of the Mount Sinai Children's Environmental Health Center and Mount Sinai Child Health and Development Institute.

\section{References}

American Journal of Medical Genetics (2010). Special Issue: Imprinted Genes and Human Disease, Am J Med Genet C Semin Med Genet 154C(3). 
Bakir F, Damluji SF, Amin-Zaki L, Murtadha M, Khalidi A, al-Rawi NY, Tikriti S, Dahahir HI, Clarkson TW, et al. (1973). Methylmercury poisoning in Iraq. Science 181 (96): 230-41.

Barker DJ (1997). Maternal nutrition, fetal nutrition, and disease in later life. Nutrition 13 (9): 807-13.

Barlow DP, Stoger R, Herrmann BG, Saito K \& Schweifer N (1991). The mouse insulin-like growth factor type- 2 receptor is imprinted and closely linked to the Tme locus. Nature 349 (6304): 84-7.

Bartolomei MS (2009). Genomic imprinting: employing and avoiding epigenetic processes. Genes Dev 23 (18): 2124-33.

Batada NN \& Hurst LD (2007). Evolution of chromosome organization driven by selection for reduced gene expression noise. Nat Genet 39 (8): 945-9.

Bernstein E \& Allis CD (2005). RNA meets chromatin. Genes Dev 19 (14): 1635-55.

Blake WJ, Kaern M, Cantor CR \& Collins JJ (2003). Noise in eukaryotic gene expression. Nature 422 (6932): 633-7.

Bourque DK, Avila L, Penaherrera M, von Dadelszen P \& Robinson WP (2010). Decreased placental methylation at the H19/IGF2 imprinting control region is associated with normotensive intrauterine growth restriction but not preeclampsia. Placenta 31 (3): 197-202.

Boyd HA, Poulsen G, Wohlfahrt J, Murray JC, Feenstra B \& Melbye M (2009). Maternal contributions to preterm delivery. Am J Epidemiol 170 (11): 1358-64.

Boyle CA, Decoufle P \& Yeargin-Allsopp M (1994). Prevalence and health impact of developmental disabilities in US children. Pediatrics 93 (3): 399-403.

Bressan FF, De Bem TH, Perecin F, Lopes FL, Ambrosio CE, Meirelles FV \& Miglino MA (2009). Unearthing the roles of imprinted genes in the placenta. Placenta 30 (10): 823-34.

Centers for Disease Control and Prevention (CDC) (2009). Prevalence of autism spectrum disorders - Autism and Developmental Disabilities Monitoring Network, United States, 2006. MMWR Surveill Summ 58 (10): 1-20.

Centers for Disease Control and Prevention (CDC) (2011). Overweight and obesity: US obesity trends. Trends by state 1985-2009. Atlanta (GA): CDC; 2011 Mar 3. Available at: http://www.cdc.gov/obesity/data/trends.html

Charalambous M, da Rocha ST \& Ferguson-Smith AC (2007). Genomic imprinting, growth control and the allocation of nutritional resources: consequences for postnatal life. Curr Opin Endocrinol Diabetes Obes 14 (1): 3-12.

Court F, Baniol M, Hagege H, Petit JS, Lelay-Taha MN, Carbonell F, Weber M, Cathala G \& Forne T (2011). Long-range chromatin interactions at the mouse Igf2/H19 locus reveal a novel paternally expressed long non-coding RNA. Nucleic Acids Res: [Epub ahead of print].

Crane JL, Shamblott MJ, Axelman J, Hsu S, Levine MA \& Germain-Lee EL (2009). Imprinting Status of Galpha(s), NESP55, and XLalphas in cell cultures derived from human embryonic germ cells: GNAS imprinting in human embryonic germ cells. Clin Transl Sci 2 (5): 355-60.

Davies W, Isles AR \& Wilkinson LS (2005). Imprinted gene expression in the brain. Neurosci Biobehav Rev 29 (3): 421-30. 
Diplas AI, Lambertini L, Lee MJ, Sperling R, Lee YL, Wetmur J \& Chen J (2009a). Differential expression of imprinted genes in normal and IUGR human placentas. Epigenetics 4 (4): 235-40.

Diplas AI, Hu J, Lee MJ, Ma YY, Lee YL, Lambertini L, Chen J \& Wetmur JG (2009b). Demonstration of all-or-none loss of imprinting in mRNA expression in single cells. Nucleic Acids Res 37 (21): 7039-46.

Doyle LW, Kitchen WH, Ford GW, Rickards AL \& Kelly EA (1989). Antenatal steroid therapy and 5-year outcome of extremely low birth weight infants. Obstet Gynecol 73 (5 Pt 1): 743-6.

Driscoll DJ, Waters MF, Williams CA, Zori RT, Glenn CC, Avidano KM \& Nicholls RD (1992). A DNA methylation imprint, determined by the sex of the parent, distinguishes the Angelman and Prader-Willi syndromes. Genomics 13 (4): 917-24.

Ehrlich M, Gama-Sosa MA, Huang LH, Midgett RM, Kuo KC, McCune RA \& Gehrke C (1982). Amount and distribution of 5-methylcytosine in human DNA from different types of tissues of cells. Nucleic Acids Res 10 (8): 2709-21.

Elowitz MB, Levine AJ, Siggia ED \& Swain PS (2002). Stochastic gene expression in a single cell. Science 297 (5584): 1183-6.

Engel SM, Berkowitz GS, Barr DB, Teitelbaum SL, Siskind J, Meisel SJ, Wetmur JG \& Wolff MS (2007). Prenatal organophosphate metabolite and organochlorine levels and performance on the Brazelton Neonatal Behavioral Assessment Scale in a multiethnic pregnancy cohort. Am J Epidemiol 165 (12): 1397-404.

Environmental Protection Agency (EPA) (2010). America's children and the environment (ACE), measure D1: percentage of children with asthma. Washington (DC):EPA; 2010 Nov 19. Available at: http://www.epa.gov/economics/children/child_illness/d1graph.html.

Eskenazi B, Harley K, Bradman A, Weltzien E, Jewell NA, Barr DB, Furlong CE \& Holland NT (2004). Association of in utero organophosphate pesticide exposure and fetal growth and length of gestation in an agricultural population. Environ Health Perspect 112 (10): 1116-24.

Federal Interagency Forum on Child and Family Statistics (2011). America's children in brief: key national indicators of well-being, 2010. Merrifield (VA): The Forum. Available at: http:/ /www.childstats.gov/americaschildren/health.asp

Fink NS, Urech C, Berger CT, Hoesli I, Holzgreve W, Bitzer J \& Alder J (2010). Maternal laboratory stress influences fetal neurobehavior: Cortisol does not provide all answers. Journal of Maternal-Fetal \& Neonatal Medicine 23 (6): 488-500.

Fraser HB, Hirsh AE, Giaever G, Kumm J \& Eisen MB (2004). Noise minimization in eukaryotic gene expression. PLoS Biol 2 (6): e137.

Gama-Sosa MA, Midgett RM, Slagel VA, Githens S, Kuo KC, Gehrke CW \& Ehrlich M (1983). Tissue-specific differences in DNA methylation in various mammals. Biochim Biophys Acta 740 (2): 212-9.

Gieni RS \& Hendzel MJ (2009). Polycomb group protein gene silencing, non-coding RNA, stem cells, and cancer. Biochem Cell Biol 87 (5): 711-46.

Godfrey KM \& Barker DJ (2000). Fetal nutrition and adult disease. Am J Clin Nutr 71 (5 Suppl): 1344S-52S.

Guilleret I, Osterheld MC, Braunschweig R, Gastineau V, Taillens S \& Benhattar J (2009). Imprinting of tumor-suppressor genes in human placenta. Epigenetics 4 (1): 62-8. 
Guo L, Choufani S, Ferreira J, Smith A, Chitayat D, Shuman C, Uxa R, Keating S, Kingdom J, et al. (2008). Altered gene expression and methylation of the human chromosome 11 imprinted region in small for gestational age (SGA) placentae. Dev Biol 320 (1): 7991.

Gupta RA, Shah N, Wang KC, Kim J, Horlings HM, Wong DJ, Tsai MC, Hung T, Argani P, et al. (2010). Long non-coding RNA HOTAIR reprograms chromatin state to promote cancer metastasis. Nature 464 (7291): 1071-6.

Haig D \& Graham C (1991). Genomic imprinting and the strange case of the insulin-like growth factor II receptor. Cell 64 (6): 1045-6.

Hamabe J, Kuroki Y, Imaizumi K, Sugimoto T, Fukushima Y, Yamaguchi A, Izumikawa Y \& Niikawa N (1991). DNA deletion and its parental origin in Angelman syndrome patients. Am J Med Genet 41 (1): 64-8.

Harada M (1978). Congenital Minamata disease: intrauterine methylmercury poisoning. Teratology 18 (2): 285-8.

Heard E, Chaumeil J, Masui O \& Okamoto I (2004). Mammalian X-chromosome inactivation: an epigenetics paradigm. Cold Spring Harb Symp Quant Biol 69: 89-102.

Heijmans BT, Kremer D, Tobi EW, Boomsma DI \& Slagboom PE (2007). Heritable rather than age-related environmental and stochastic factors dominate variation in DNA methylation of the human IGF2/H19 locus. Hum Mol Genet 16 (5): 547-54.

Herbst AL, Hubby MM, Azizi F \& Makii MM (1981). Reproductive and gynecologic surgical experience in diethylstilbestrol-exposed daughters. Am J Obstet Gynecol 141 (8): 1019-28.

Horike S, Cai S, Miyano M, Cheng JF \& Kohwi-Shigematsu T (2005). Loss of silentchromatin looping and impaired imprinting of DLX5 in Rett syndrome. Nat Genet 37 (1): 31-40.

Hu D \& Cross JC (2010). Development and function of trophoblast giant cells in the rodent placenta. Int J Dev Biol 54 (2-3): 341-54.

Hutter B, Bieg M, Helms V \& Paulsen M (2010). Divergence of imprinted genes during mammalian evolution. BMC Evol Biol 10 (1): 116.

Isles AR (2009). Evolution of genomic imprinting in humans: does bipedalism have a role? Trends Genet 25 (11): 495-500.

Jones KL \& Smith DW (1973). Recognition of the fetal alcohol syndrome in early infancy. Lancet 302 (7836): 999-1001.

Kacem S \& Feil R (2009). Chromatin mechanisms in genomic imprinting. Mamm Genome 20 (9-10): 544-56.

Kanayama N, Takahashi K, Matsuura T, Sugimura M, Kobayashi T, Moniwa N, Tomita M \& Nakayama K (2002). Deficiency in p57Kip2 expression induces preeclampsia-like symptoms in mice. Mol Hum Reprod 8 (12): 1129-35.

Kawahara M, Morita S, Takahashi N \& Kono T (2009). Defining contributions of paternally methylated imprinted genes at the Igf2-H19 and Dlk1-Gt12 domains to mouse placentation by transcriptomic analysis. J Biol Chem 284 (26): 17751-65.

Kent L, Bowdin S, Kirby GA, Cooper WN \& Maher ER (2008). Beckwith Weidemann syndrome: a behavioral phenotype-genotype study. Am J Med Genet B Neuropsychiatr Genet 147B (7): 1295-7.

Khan K, Factor-Litvak P, Wasserman GA, Liu X, Ahmed E, Parvez F, Slavkovich V, Levy D, Mey J, et al. (2011). Manganese Exposure from Drinking Water and Children's 
Classroom Behavior in Bangladesh. Environ Health Perspect: [Epub ahead of print].

Lambertini L, Diplas AI, Lee MJ, Sperling R, Chen J \& Wetmur J (2008). A sensitive functional assay reveals frequent loss of genomic imprinting in human placenta. Epigenetics 3 (5): 261-9.

Lambertini L, Diplas AI, Wetmur J, Lee MJ \& Chen J (2009). Evaluation of genomic imprinting employing the analysis of Loss Of Imprinting (LOI) at the RNA level: preliminary results. Eur J Oncol 14 (3): 161-9.

Lambertini L, Lee TL, Chan WY, Lee MJ, Diplas AI, Wetmur JG \& Chen J (2011). Differential methylation of imprinted genes in growth-restricted placentas. Reprod Sci: [Epub ahead of print].

Landrigan PJ, Whitworth RH, Baloh RW, Staehling NW, Barthel WF \& Rosenblum BF (1975). Neuropsychological dysfunction in children with chronic low-level lead absorption. Lancet 1 (7909): 708-12.

Landrigan PJ \& Goldman LR (2011). Children's vulnerability to toxic chemicals: a challenge and opportunity to strengthen health and environmental policy. Health Aff (Millwood) 30 (5): 842-50.

Lee JT (2009). Lessons from X-chromosome inactivation: long ncRNA as guides and tethers to the epigenome. Genes Dev 23 (16): 1831-42.

Lefevre P, Witham J, Lacroix CE, Cockerill PN \& Bonifer C (2008). The LPS-induced transcriptional upregulation of the chicken lysozyme locus involves CTCF eviction and noncoding RNA transcription. Mol Cell 32 (1): 129-39.

Lemoine P, Harousseau H, Borteyru JP \& Menuet JC (1968). Les enfants des parents alcooliques: Anomalies observées. A propos de 127 cas. Ouest Medical 21: 476-82.

Lester BM \& Padbury JF (2009). Third pathophysiology of prenatal cocaine exposure. Dev Neurosci 31 (1-2): 23-35.

Lewis A \& Reik W (2006). How imprinting centres work. Cytogenet Genome Res 113 (1-4): 81-9.

Li L, Keverne EB, Aparicio SA, Ishino F, Barton SC \& Surani MA (1999). Regulation of maternal behavior and offspring growth by paternally expressed Peg3. Science 284 (5412): 330-3.

Li Q, O'Malley ME, Bartlett DL \& Guo ZS (2011). Homeobox gene Rhox5 is regulated by epigenetic mechanisms in cancer and stem cells and promotes cancer growth. Mol Cancer 10: 63.

Little J (2009). Invited commentary: maternal effects in preterm birth--effects of maternal genotype, mitochondrial DNA, imprinting, or environment? Am J Epidemiol 170 (11): 1382-5.

Liu JH (2009). Endocrinology of Pregnancy. In: Maternal-Fetal Medicine, Principles and Practice. 6th Edition. Resnik C ed., 111-24, Saunders Elsevier. Philadelphia (PA), USA.

Lumey LH (1998). Reproductive outcomes in women prenatally exposed to undernutrition: a review of findings from the Dutch famine birth cohort. Proc Nutr Soc 57 (1): 12935.

Maccani MA \& Marsit CJ (2009). Epigenetics in the placenta. Am J Reprod Immunol 62 (2): 78-89. 
Marsit CJ, Lambertini L, Maccani M, Koestler D, Houseman EA, Gagne L, Padbury JF, Lester BM \& Chen J (2011). Imprinted Gene Expression in the Placenta is Associated with Infant Neurobehavioral Outcomes. J Pediatr; e-pub ahead of print.

McBride WG (1961). Thalidomide and Congenital Abnormalities. Lancet 2: 1358.

McGrath J \& Solter D (1984). Completion of mouse embryogenesis requires both the maternal and paternal genomes. Cell 37 (1): 179-83.

McMinn J, Wei M, Schupf N, Cusmai J, Johnson EB, Smith AC, Weksberg R, Thaker HM \& Tycko B (2006). Unbalanced placental expression of imprinted genes in human intrauterine growth restriction. Placenta 27 (6-7): 540-9.

Mendiola J, Stahlhut RW, Jorgensen N, Liu F \& Swan SH (2011). Shorter anogenital distance predicts poorer semen quality in young men in Rochester, new york. Environ Health Perspect 119 (7): 958-63.

Meyer MB, Jonas BS \& Tonascia JA (1976). Perinatal events associated with maternal smoking during pregnancy. Am J Epidemiol 103 (5): 464-76.

Minard ME, Jain AK \& Barton MC (2009). Analysis of epigenetic alterations to chromatin during development. Genesis 47 (8): 559-72.

Mohammad F, Mondal T \& Kanduri C (2009). Epigenetics of imprinted long noncoding RNAs. Epigenetics 4 (5): 277-86.

Molloy AM, Kirke P, Hillary I, Weir DG \& Scott JM (1985). Maternal serum folate and vitamin B12 concentrations in pregnancies associated with neural tube defects. Arch Dis Child 60 (7): 660-5.

Monk D, Arnaud P, Apostolidou S, Hills FA, Kelsey G, Stanier P, Feil R \& Moore GE (2006). Limited evolutionary conservation of imprinting in the human placenta. Proc Natl Acad Sci U S A 103 (17): 6623-8.

Moore T \& Haig D (1991). Genomic imprinting in mammalian development: a parental tugof-war. Trends Genet 7 (2): 45-9.

National Institutes of Health / National Cancer Institute (NIH/NCI) (2011). Surveillance epidemiology and end results (Homepage). Rockville (MD). Available at: http://seer.cancer.gov

Ordonez JV, Carrillo JA, Miranda M \& Gale JL (1966). [Epidemiologic study of a disease believed to be encephalitis in the region of the highlands of Guatemala]. Bol Oficina Sanit Panam 60 (6): 510-9.

Ozbudak EM, Thattai M, Kurtser I, Grossman AD \& van Oudenaarden A (2002). Regulation of noise in the expression of a single gene. Nat Genet 31 (1): 69-73.

Parvez F, Wasserman GA, Factor-Litvak P, Liu X, Slavkovich V, Siddique AB, Sultana R, Islam T, Levy D, et al. (2011). Arsenic Exposure and Motor Function among Children in Bangladesh. Environ Health Perspect: [Epub ahead of print].

Pastor PN \& Reuben CA (2008). Diagnosed attention deficit hyperactivity disorder and learning disability: United States, 2004-2006. Vital Health Stat 10 (237): 1-14.

Paulozzi LJ, Erickson JD \& Jackson RJ (1997). Hypospadias trends in two US surveillance systems. Pediatrics 100 (5): 831-4.

Perera FP, Rauh V, Tsai WY, Kinney P, Camann D, Barr D, Bernert T, Garfinkel R, Tu YH, et al. (2003). Effects of transplacental exposure to environmental pollutants on birth outcomes in a multiethnic population. Environ Health Perspect 111 (2): 201-5.

Perera FP \& Herbstman J (2011). Prenatal Environmental Exposures, Epigenetics, and Disease. Reprod Toxicol 31 (3): 363-73. 
Perry JK, Lins RJ, Lobie PE \& Mitchell MD (2010). Regulation of invasive growth: similar epigenetic mechanisms underpin tumour progression and implantation in human pregnancy. Clin Sci (Lond) 118 (7): 451-7.

Petraglia F, Coukos G, Volpe A, Genazzani AR \& Vale W (1991). Involvement of placental neurohormones in human parturition. Ann N Y Acad Sci 622: 331-40.

Pierce PE, Thompson JF, Likosky WH, Nickey LN, Barthel WF \& Hinman AR (1972). Alkyl mercury poisoning in humans. Report of an outbreak. JAMA 220 (11): 1439-42.

Plagge A, Kelsey G \& Germain-Lee EL (2008). Physiological functions of the imprinted Gnas locus and its protein variants Galpha(s) and XLalpha(s) in human and mouse. J Endocrinol 196 (2): 193-214.

Pozharny Y, Lambertini L, Ma Y, Ferrara L, Litton CG, Diplas A, Jacobs AR, Chen J, Stone $\mathrm{JL}$, et al. (2010). Genomic loss of imprinting in first-trimester human placenta. Am J Obstet Gynecol 202 (4): 391 e1-8.

Qureshi IA \& Mehler MF (2011). Advances in Epigenetics and Epigenomics for Neurodegenerative Diseases. Curr Neurol Neurosci Rep: [Epub ahead of print].

Ravelli GP, Stein ZA \& Susser MW (1976). Obesity in young men after famine exposure in utero and early infancy. N Engl J Med 295 (7): 349-53.

Reik W, Dean W \& Walter J (2001). Epigenetic reprogramming in mammalian development. Science 293 (5532): 1089-93.

Roseboom T, de Rooij S \& Painter R (2006). The Dutch famine and its long-term consequences for adult health. Early Hum Dev 82 (8): 485-91.

Royo H \& Cavaille J (2008). Non-coding RNAs in imprinted gene clusters. Biol Cell 100 (3): 149-66.

Santos F \& Dean W (2004). Epigenetic reprogramming during early development in mammals. Reproduction 127 (6): 643-51.

Sasaky H \& Ishino I, Eds. (2006). Genomic Imprinting, Cytogenet Genome Res 113 (Complete Issue).

Song S, Wang W \& Hu P (2009). Famine, death, and madness: schizophrenia in early adulthood after prenatal exposure to the Chinese Great Leap Forward Famine. Soc Sci Med 68 (7): 1315-21.

Stadtfeld M, Apostolou E, Akutsu H, Fukuda A, Follett P, Natesan S, Kono T, Shioda T \& Hochedlinger K (2010). Aberrant silencing of imprinted genes on chromosome 12qF1 in mouse induced pluripotent stem cells. Nature 465 (7295): 175-81.

Steinhoff C, Paulsen M, Kielbasa S, Walter J \& Vingron M (2009). Expression profile and transcription factor binding site exploration of imprinted genes in human and mouse. BMC Genomics 10: 144.

Susser E, Neugebauer R, Hoek HW, Brown AS, Lin S, Labovitz D \& Gorman JM (1996). Schizophrenia after prenatal famine. Further evidence. Arch Gen Psychiatry 53 (1): 25-31.

Susser E, Hoek HW \& Brown A (1998). Neurodevelopmental disorders after prenatal famine: The story of the Dutch Famine Study. Am J Epidemiol 147 (3): 213-6.

Swan SH, Main KM, Liu F, Stewart SL, Kruse RL, Calafat AM, Mao CS, Redmon JB, Ternand CL, et al. (2005). Decrease in anogenital distance among male infants with prenatal phthalate exposure. Environ Health Perspect 113 (8): 1056-61.

Tabano S, Colapietro P, Cetin I, Grati FR, Zanutto S, Mando C, Antonazzo P, Pileri P, Rossella F, et al. (2010). Epigenetic modulation of the IGF2/H19 imprinted domain 
in human embryonic and extra-embryonic compartments and its possible role in fetal growth restriction. Epigenetics 5 (4): 313-24.

Taft RJ, Pheasant M \& Mattick JS (2007). The relationship between non-protein-coding DNA and eukaryotic complexity. Bioessays 29 (3): 288-99.

Taussig HB (1962). A study of the German outbreak of phocomelia. The thalidomide syndrome. JAMA 180: 1106-14.

Thorp JA, Jones PG, Knox E \& Clark RH (2002). Does antenatal corticosteroid therapy affect birth weight and head circumference? Obstet Gynecol 99 (1): 101-8.

Tobi EW, Lumey LH, Talens RP, Kremer D, Putter H, Stein AD, Slagboom PE \& Heijmans BT (2009). DNA methylation differences after exposure to prenatal famine are common and timing- and sex-specific. Hum Mol Genet 18 (21): 4046-53.

Trasande L (2011). Quantifying the economic consequences of childhood obesity and potential benefits of interventions. Expert Rev Pharmacoecon Outcomes Res 11 (1): 47-50.

Trasande L \& Liu Y (2011). Reducing the staggering costs of environmental disease in children, estimated at $\$ 76.6$ billion in 2008. Health Aff (Millwood) 30 (5): 863-70.

Tunster SJ, Tycko B \& John RM (2010). The imprinted Phlda2 gene regulates extraembryonic energy stores. Mol Cell Biol 30 (1): 295-306.

Tycko B (2006). Imprinted genes in placental growth and obstetric disorders. Cytogenet Genome Res 113 (1-4): 271-8.

Ulleland CN (1972). The offspring of alcoholic mothers. Ann N Y Acad Sci 197: 167-9.

Underwood PB, Kesler KF, O'Lane JM \& Callagan DA (1967). Parental smoking empirically related to pregnancy outcome. Obstet Gynecol 29 (1): 1-8.

Vu LT, Nobuhara KK, Laurent C \& Shaw GM (2008). Increasing prevalence of gastroschisis: population-based study in California. J Pediatr 152 (6): 807-11.

$\mathrm{Vu}$ TH, Nguyen AH \& Hoffman AR (2010). Loss of IGF2 imprinting is associated with abrogation of long-range intrachromosomal interactions in human cancer cells. Hum Mol Genet 19 (5): 901-19.

Williams CA, Zori RT, Stone JW, Gray BA, Cantu ES \& Ostrer H (1990). Maternal origin of 15q11-13 deletions in Angelman syndrome suggests a role for genomic imprinting. Am J Med Genet 35 (3): 350-3.

Wolff MS, Engel S, Berkowitz G, Teitelbaum S, Siskind J, Barr DB \& Wetmur J (2007). Prenatal pesticide and PCB exposures and birth outcomes. Pediatr Res 61 (2): 24350.

Yang PK \& Kuroda MI (2007). Noncoding RNAs and intranuclear positioning in monoallelic gene expression. Cell 128 (4): 777-86.

Yazgan O \& Krebs JE (2007). Noncoding but nonexpendable: transcriptional regulation by large noncoding RNA in eukaryotes. Biochem Cell Biol 85 (4): 484-96.

Yen SS (1991). Endocrine-metabolic adaptions in pregnancy. In: Reproductive Endocrinology. 3rd Edition. Yen SS and Jaffe RB eds, 963-70, WB Saunders. Philadelphia (PA), USA.

Yen SS (1994). The placenta as the third brain. J Reprod Med 39 (4): 277-80.

Yu L, Chen M, Zhao D, Yi P, Lu L, Han J, Zheng X, Zhou Y \& Li L (2009). The H19 gene imprinting in normal pregnancy and pre-eclampsia. Placenta 30 (5): 443-7.

Yu S, Gavrilova O, Chen H, Lee R, Liu J, Pacak K, Parlow AF, Quon MJ, Reitman ML, et al. (2000). Paternal versus maternal transmission of a stimulatory G-protein alpha 
subunit knockout produces opposite effects on energy metabolism. J Clin Invest 105 (5): 615-23.

Zaitoun I, Downs KM, Rosa GJ \& Khatib H (2010). Upregulation of imprinted genes in mice: an insight into the intensity of gene expression and the evolution of genomic imprinting. Epigenetics 5 (2): 149-58.

Zhang TY \& Meaney MJ (2010). Epigenetics and the environmental regulation of the genome and its function. Annu Rev Psychol 61: 439-66, C1-3.

Zlatanova J \& Caiafa P (2009). CCCTC-binding factor: to loop or to bridge. Cell Mol Life Sci 66 (10): 1647-60. 


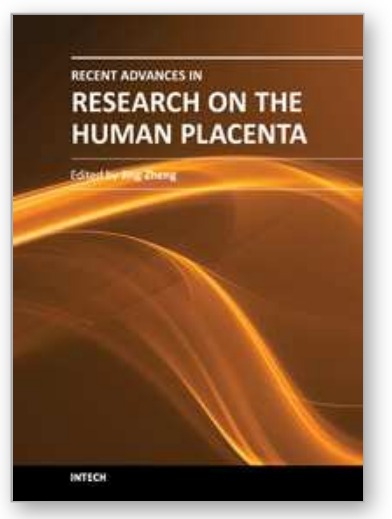

\author{
Recent Advances in Research on the Human Placenta \\ Edited by Dr. Jing Zheng
}

ISBN 978-953-51-0194-9

Hard cover, 428 pages

Publisher InTech

Published online 07, March, 2012

Published in print edition March, 2012

This book contains the total of 19 chapters, each of which is written by one or several experts in the corresponding field. The objective of this book is to provide a comprehensive and most updated overview of the human placenta, including current advances and future directions in the early detection, recognition, and management of placental abnormalities as well as the most common placental structure and functions, abnormalities, toxicology, infections, and pathologies. It also includes a highly controversial topic, therapeutic applications of the human placenta. A collection of articles presented by active investigators provides a clear update in the area of placental research for medical students, nurse practitioners, practicing clinicians, and biomedical researchers in the fields of obstetrics, pediatrics, family practice, genetics, and others who may be interested in human placentas.

\title{
How to reference
}

In order to correctly reference this scholarly work, feel free to copy and paste the following:

Luca Lambertini, Men-Jean Lee, Carmen J. Marsit and Jia Chen (2012). Genomic Imprinting in Human Placenta, Recent Advances in Research on the Human Placenta, Dr. Jing Zheng (Ed.), ISBN: 978-953-510194-9, InTech, Available from: http://www.intechopen.com/books/recent-advances-in-research-on-thehuman-placenta/genomic-imprinting-in-human-placenta

\section{INTECH}

open science | open minds

\author{
InTech Europe \\ University Campus STeP Ri \\ Slavka Krautzeka 83/A \\ 51000 Rijeka, Croatia \\ Phone: +385 (51) 770447 \\ Fax: +385 (51) 686166 \\ www.intechopen.com
}

\author{
InTech China \\ Unit 405, Office Block, Hotel Equatorial Shanghai \\ No.65, Yan An Road (West), Shanghai, 200040, China \\ 中国上海市延安西路65号上海国际贵都大饭店办公楼 405 单元 \\ Phone: +86-21-62489820 \\ Fax: $+86-21-62489821$
}


(C) 2012 The Author(s). Licensee IntechOpen. This is an open access article distributed under the terms of the Creative Commons Attribution 3.0 License, which permits unrestricted use, distribution, and reproduction in any medium, provided the original work is properly cited. 